\title{
Association between developmental dental anomalies, early childhood caries and oral hygiene status of 3-5-year-old children in lle-Ife, Nigeria
}

Morenike Oluwatoyin Folayan ${ }^{1 *}$ D, Michael Alade ${ }^{2}$, Abiola Adeniyi ${ }^{3}$, Maha El Tantawi ${ }^{4}$ and Tracy L. Finlayson ${ }^{5}$

\begin{abstract}
Background: To determine the association between developmental dental anomalies (DDA), early childhood caries (ECC) and oral hygiene status of 3-5-year-old children resident in lle-lfe, Nigeria.

Methods: This was a cross-sectional study. We analyzed data for 3-5-year-olds extracted from the dataset of a household survey collected to determine the association between ECC and maternal psychosocial wellbeing in children 0-5-year-old. The outcome variables for the study were ECC and poor oral hygiene. The explanatory variable was the presence of developmental dental anomalies (supernumerary, supplemental, mesiodens, hypodontia, macrodontia, microdontia, peg-shaped lateral, dens evaginatus, dens invaginatus, talons cusp, fusion/ germination, hypoplasia, hypomineralized second molar, fluorosis, amelogenesis imperfecta). The prevalence of each anomaly was determined. Poisson regression analysis was conducted to determine the association between presence of developmental dental anomalies, ECC and oral hygiene status. The model was adjusted for sex, age and socioeconomic status.

Results: Of the 918 children examined, 75 (8.2\%) had developmental dental anomalies, 43 (4.7\%) had ECC, and 38 (4.1\%) had poor oral hygiene. The most prevalent developmental dental anomalies was enamel hypoplasia (3.9\%). Of the 43 children with ECC, 6 (14.0\%) had enamel hypoplasia and 3 (7.6\%) had hypomineralized second primary molar. There was a significant association between ECC and enamel hypoplasia $(p<0.001)$ and a borderline association between ECC and hypomineralized second primary molars $(p=0.05)$. The proportion of children with poor oral hygiene (PR: 2.03; 95\% Cl: 0.91-4.56; $p=0.09$ ) and ECC (PR: 2.02; 95\% Cl: 0.92-4.46; $p=0.08$ ) who had developmental dental anomalies was twice that of children with good oral hygiene and without ECC respectively, although the differences did not reach statistical significance.

Conclusions: Enamel hypoplasia and hypomineralized second primary molars are developmental dental anomalies associated with ECC. developmental dental anomalies also increases the probability of having poor oral hygiene in the population studied.
\end{abstract}

Keywords: Early childhood caries, Developmental anomalies, Nigeria, Preschool children, Hypomineralized second primary molar, Enamel hypoplasia, Oral hygiene

\footnotetext{
* Correspondence: toyinukpong@yahoo.co.uk

'Obafemi Awolowo University, Ile-Ife, Nigeria

Full list of author information is available at the end of the article
}

(c) The Author(s). 2019 Open Access This article is distributed under the terms of the Creative Commons Attribution 4.0 International License (http://creativecommons.org/licenses/by/4.0/), which permits unrestricted use, distribution, and reproduction in any medium, provided you give appropriate credit to the original author(s) and the source, provide a link to the Creative Commons license, and indicate if changes were made. The Creative Commons Public Domain Dedication waiver (http://creativecommons.org/publicdomain/zero/1.0/) applies to the data made available in this article, unless otherwise stated. 


\section{Background}

Dental hard-tissue anomalies consist of anomalies of tooth shape, tooth size, tooth structure, tooth number, and tooth position [1]. The prevalence of these lesions can differ significantly across and among populations. Population-specific data on developmental dental anomalies (DDA) are of epidemiological and anthropological importance because the inter-relatedness of many clinical dental features - normal and pathological - reflects the pleiotropic effects of genes during tooth development. The features provide insight into population dynamics and evolution and are helpful for the fields of dental paleopathology [2], clinical pediatric dentistry, and orthodontic practice as well as for understanding the evolution of human dentition [3].

Only 90 (46.6\%) of the 193 United Nations countries have English-language publications on the epidemiology of DDA, despite several years of research on the subject. Data were least available for Africa, [3] and few studies had been conducted in Nigeria [4-6]. This study provides data on clinically diagnosed DDA in the primary dentition of young children in a suburban population in Nigeria. The aim of the study was to determine the association between ECC, oral hygiene status and DDA.

\section{Methods}

This is a cross-sectional study. Data on DDA were collected as part of a household survey to determine the prevalence of early childhood caries (ECC) and associated maternal psychosocial risk factors. The study participants were 1549 children aged 6 to 71 months resident in Ife Central Local Government Area of Osun, State, Ile-Ife, a semi-urban community. The survey was conducted between December 2018 and January 2019.

\section{Sample size}

The minimum sample size for the study was calculated using the formula for cross-sectional studies in populations greater than 10,000 [7]. The variables for determining the sample size included the prevalence of ECC prevalence which was $6.6 \%$ [8], the margin of error was $5 \%$, and the confidence level was $95 \%$. The minimum sample size required for the study was 1439 motherchild dyads.

\section{Sampling and recruitment procedure}

A multi-stage sampling technique was used for the study. The first stage consisted of selecting 70 of the 700 enumeration areas in the local government by a simple random, balloting method. This percentage of the population is considered representative for a household survey [9]. The second stage consisted of selecting eligible households within the enumeration sites of the survey. At each of the enumeration sites, every other household on each street was eligible for recruitment of a mother- child dyad. The third stage consisted of selecting respondents for an interview and clinical examination.

Only one child and mother dyad in each household was eligible for participation in the study. Only children who were below the age of 6 years, who were living with a caregiver, who were present at the time of the survey and for whom parental consent for study participation was obtained, were recruited for the study. Children who had chronic medical conditions that required prolonged use of sweetened medications and those with medical conditions that increased their risk for caries were excluded from the study. Where there was more than one child eligible for study participation, the study participant was identified by balloting. The other child (ren) was/were offered the opportunity to have a clinical examination. All participants were informed about the screening outcome and referred for treatment when oral diseases were identified. Treatment for ECC was offered free to study participants.

Whenever a household declined (19 households declined) to participate, the next eligible household was substituted. The number of participants to be recruited from each enumeration site was determined by proportioning the study's sample size per the population of the enumeration site. Ethical approval for the study was obtained from the Obafemi Awolowo University Teaching Hospitals Complex Health Research Ethics Committee (NHREC/27/01/2009a \& IRB/EC/0004553).

\section{Data collection}

Data obtained included the children's socio-demographic characteristics (age, sex, and socioeconomic status). The definition of socioeconomic status was based on a multiple-item index [10] that had been used in prior studies in Nigeria $[10,11]$. The composite score was based on maternal occupation and paternal education. Enrolled children were classified according to one of five socioeconomic classes: class I, upper class; class II, uppermiddle class; class III, middle class; class IV, lower middle class; and class V, lower class. The classes were then categorized as high (Classes I and II), middle (Class III), and low (Classes IV and V).

The oral examinations were conducted by five calibrated dentists. Intra-examiner agreement for each of the dentists was calculated by use of the paired sample correlation, whereas the inter-examiner agreement (between the dentists and the trainer) was calculated by use of Cohen's kappa coefficient. The intra- and interexaminer reliability tests were all greater than 0.80 , which is considered an acceps level of agreement. Children were examined under natural light, either sitting on a chair or on their mother's lap.

The teeth were examined wet for the oral hygiene status assessment; thereafter, debris was removed with 
gauze before examination for the presence of ECC and DDA. Oral hygiene was assessed by use of the index of Greene and Vermillion [12]. The index teeth and surfaces examined were the facial and lingual surfaces of teeth number $51,55,65,71,75$, and 85 . The debris and calculus scores were recorded, added, and divided by the number of surfaces examined to get the OHI-S score. Oral hygiene was scored good when the scores ranged from 0.0 to 1.2; fair when the scores ranged from 1.3 to 3.0; or poor when the scores was 3.1 and above. For children who did not have the index teeth, all the teeth present were scored, and their average determined before being classified.

ECC was determined using the decayed-missing-filled teeth ( $\mathrm{dmft}$ ) index as recommended by the World Health Organization [13]. The dmft score was obtained by adding the $\mathrm{d}, \mathrm{m}$ and $\mathrm{f}$ scores for each child. ECC was considered present when the $\mathrm{dmft}$ score was $>0$ and absent when the dmft was 0 .

The presence or absence of any DDA listed in Table 1 was determined according to the criteria of Temilola et al. [5] and Folayan et al. [14]. Also, hypomineralized primary second molar was defined as demarcated white, yellow or brown opacities that were greater than or equal to $2 \mathrm{~mm}$ in diameter, present on any of the surfaces of the primary second molar [15, 16]. Fluorosis assessed as presence or absence of tooth mottling [17]. A diagnosis of amelogenesis imperfecta was made when there was enamel hypoplasia and/or hypomaturation or hypocalcification randomly affecting multiple teeth in no depictable chronological order [18].

\section{Data analysis}

Data for this study were derived from the 918 young children aged 3-5 years old who had all their primary teeth erupted. Tests of association were conducted using chi-square or fisher test where appropriate. Descriptive analysis was conducted to determine the prevalence of each lesion. Multivariable logistic regression was conducted by use of the Poisson regression analysis to determine if the presence of a DDA, ECC and oral hygiene was associated. The estimated coefficients, expressed as prevalence ratios (PRs) and their 95\% confidence intervals, were calculated. We chose to use the Poisson regression analysis because it reduces the risk for overestimation of the prevalence ratio especially when an adjusted estimate needs to be made. The analysis also used a robust variance estimator to allow for direct estimation of the PRs. Statistical analyses were conducted with Intercooled STATA (release 15) for windows. Statistical significance was inferred at $p<0.05$.

\section{Results}

Seventy-five (8.2\%) children had DDA. Fifty-eight (77.3\%) of the children with DDA had one anomaly, 12 (15.4\%) had two anomalies, and five (6.7\%) had three or more anomalies. The prevalence of DDA by sex and socioeconomic status are listed in Table 1; the most prevalent lesions were enamel hypoplasia (3.9\%), hypomineralized primary second molar $(2.0 \%)$, and pegshaped laterals $(1.2 \%)$. There were no significant differences in the prevalence of any of the DDA by sex and socioeconomic status.

Table 2 shows the prevalence of DDA by ECC and oral hygiene status. ECC was only identified in children with enamel hypoplasia and hypomineralized primary second molar. Six (14.0\%) and three (7.0\%) children with ECC had enamel hypoplasia and hypomineralized primary second molar, respectively. There was a statistically significant association between ECC, enamel hypoplasia $\left(\mathrm{x}^{2}=12.24 ; p<0.001\right)$ and hypomineralized second molar (Fisher's exact test: $p=0.05$ ): a higher proportion of children with ECC had enamel hypoplasia $(3.4 \%$ vs $14.0 \%)$ and hypomineralized second molar $(1.8 \%$ vs $7.0 \%)$ when compared with children without ECC.

Also, there were 267 (29.1\%) children with fair oral hygiene and $38(4.1 \%)$ with poor oral hygiene. More children with microdontia ( $2.6 \%$ vs $0.7 \%$ vs $0.0 \% ; p=0.007$ ), hypodontia ( $7.9 \%$ vs $0.8 \%$ vs $0.0 \%, p=0.03)$, and mesiodens $(5.3 \%$ vs $0.5 \%$ vs $0.8 \%, \mathrm{p}=0.03)$ had poor oral hygiene compared to those with good and fair oral hygiene respectively.

Table 3 shows the variables associated with the presence of DDA in the primary dentition. The proportion of children with DDA who had poor oral hygiene was twice that of children who had good oral hygiene (PR: 2.03; 95\% CI: 0.91-4.56; $p=0.09$ ), and the proportion of children with DDA who had ECC was twice that of children without ECC (PR: 2.02; 95\% CI: 0.92-4.46; $p=0.08$ ), but these differences were not statistically significant.

\section{Discussion}

This study adds new information to the existing evidence on the prevalence of DDA in a low- middle-income suburban population in Nigeria. It is the first study on the prevalence of DDA among preschool-aged children in Nigeria, although a prior study reported the prevalence of DDA lesions in primary teeth of children aged 6-12 years old [6]. The present study is the first to provide population-level estimates of the prevalence of hypomineralized primary second molar, fluorosis, and amelogenesis imperfecta in children aged $3-5$ years old in Nigeria. It is also the first to report an association between ECC, enamel hypoplasia and hypomineralized primary second molar in Nigeria. Although several studies have shown that enamel hypoplasia was the most prevalent DDA in Nigeria [19], and that there was an association between caries and hypomineralized primary second molar [20], none highlighted a relationship between caries and enamel hypoplasia. Prior to this study, 
Table 1 Prevalence of clinically diagnosed developmental dental hard tissue anomalies by sex and socioeconomic status in 3-5 year old children in lle-lfe $(N=918)$

\begin{tabular}{|c|c|c|c|c|c|c|c|c|c|c|c|c|c|c|c|}
\hline \multirow[t]{3}{*}{ Variables } & & \multicolumn{5}{|l|}{ Sex } & \multicolumn{7}{|c|}{$\underline{\text { Socio-economic status }}$} & \multirow{2}{*}{\multicolumn{2}{|c|}{$\begin{array}{l}\text { TOTAL } \\
N=918\end{array}$}} \\
\hline & & \multicolumn{2}{|c|}{ Male $n=495$} & \multicolumn{2}{|c|}{$\begin{array}{l}\text { Female } n= \\
423\end{array}$} & \multirow[t]{2}{*}{$\begin{array}{l}P \\
\text { value }\end{array}$} & \multicolumn{2}{|l|}{$\begin{array}{l}\text { High } \\
n=291\end{array}$} & \multicolumn{2}{|l|}{$\begin{array}{l}\text { Middle } \\
n=402\end{array}$} & \multicolumn{2}{|l|}{$\begin{array}{l}\text { Low } \\
n=225\end{array}$} & \multirow[t]{2}{*}{$\begin{array}{l}P \\
\text { value }\end{array}$} & & \\
\hline & & Number & $\%$ & Number & $\%$ & & Number & $\%$ & Number & $\%$ & Number & $\%$ & & Number & $\%$ \\
\hline \multirow[t]{2}{*}{ Supernumerary } & Absent & 494 & 99.8 & 420 & 99.3 & 0.34 & 290 & 99.7 & 400 & 99.5 & 224 & 99.5 & 1.00 & 914 & 99.6 \\
\hline & Present & 1 & 0.2 & 3 & 0.7 & & 1 & 0.3 & 2 & 0.5 & 1 & 0.5 & & 4 & 0.4 \\
\hline \multirow[t]{2}{*}{ Supplemental } & Absent & 493 & 99.4 & 420 & 99.3 & 1.00 & 290 & 99.7 & 400 & 99.5 & 222 & 98.6 & 0.39 & 912 & 99.3 \\
\hline & Present & 3 & 0.6 & 3 & 0.7 & & 1 & 0.3 & 2 & 0.5 & 3 & 1.4 & & 6 & 0.7 \\
\hline \multirow[t]{2}{*}{ Mesiodens } & Absent & 492 & 99.6 & 418 & 98.8 & 0.26 & 289 & 99.3 & 400 & 99.5 & 222 & 98.6 & 0.55 & 911 & 99.2 \\
\hline & Present & 2 & 0.4 & 5 & 1.2 & & 2 & 0.7 & 2 & 0.5 & 3 & 1.4 & & 7 & 0.8 \\
\hline \multirow[t]{2}{*}{ Hypodontia } & Absent & 493 & 99.4 & 418 & 98.8 & 0.48 & 288 & 99.0 & 399 & 99.2 & 223 & 99.1 & 0.91 & 910 & 99. \\
\hline & Present & 3 & 0.6 & 5 & 1.2 & & 3 & 1.0 & 3 & 0.8 & 2 & 0.9 & & 8 & 0.9 \\
\hline \multirow[t]{2}{*}{ Macrodontia } & Absent & 494 & 99.8 & 419 & 99.0 & 1.90 & 290 & 99.6 & 399 & 99.2 & 224 & 99.5 & 0.86 & 913 & 99.4 \\
\hline & Present & 1 & 0.2 & 4 & 1.0 & & 1 & 0.4 & 3 & 0.8 & 1 & 0.5 & & 5 & 0.6 \\
\hline \multirow[t]{2}{*}{ Microdontia } & Absent & 493 & 99.6 & 419 & 99.0 & 0.42 & 289 & 99.3 & 400 & 99.5 & 223 & 99.1 & 0.87 & 912 & 99.3 \\
\hline & Present & 2 & 0.4 & 4 & 1.0 & & 2 & 0.7 & 2 & 0.5 & 2 & 0.9 & & 6 & 0.7 \\
\hline \multirow[t]{2}{*}{ peg-shaped lateral } & Absent & 491 & 99.2 & 416 & 98.3 & 0.36 & 288 & 98.9 & 398 & 99.0 & 221 & 98.2 & 0.69 & 907 & 98.8 \\
\hline & Present & 4 & 0.8 & 7 & 1.7 & & 3 & 1.1 & 4 & 1.0 & 4 & 1.8 & & 11 & 1.2 \\
\hline \multirow[t]{2}{*}{ Dens evaginatus } & Absent & 494 & 99.8 & 420 & 99.3 & 0.34 & 290 & 99.7 & 400 & 99.5 & 224 & 99.5 & 1.00 & 914 & 99.6 \\
\hline & Present & 1 & 0.2 & 3 & 0.7 & & 1 & 0.3 & 2 & 0.5 & 1 & 0.5 & & 4 & 0.4 \\
\hline \multirow[t]{2}{*}{ Dens invaginatus } & Absent & 493 & 99.6 & 420 & 99.3 & 0.67 & 290 & 99.7 & 400 & 99.5 & 223 & 99.1 & 0.73 & 913 & 99.4 \\
\hline & Present & 2 & 0.4 & 3 & 0.7 & & 1 & 0.3 & 2 & 0.5 & 2 & 0.9 & & 5 & 0.6 \\
\hline \multirow[t]{2}{*}{ Talons cusp } & Absent & 492 & 99.4 & 420 & 99.3 & 1.00 & 290 & 99.7 & 400 & 99.5 & 222 & 98.6 & 0.50 & 912 & 99.3 \\
\hline & Present & 3 & 0.6 & 3 & 0.7 & & 1 & 0.3 & 2 & 0.5 & 3 & 1.4 & & 6 & 0.7 \\
\hline \multirow[t]{2}{*}{ Fusion/gemination } & Absent & 494 & 99.8 & 420 & 99.3 & 0.34 & 290 & 99.7 & 401 & 99.7 & 223 & 99.1 & 0.47 & 914 & 99.6 \\
\hline & Present & 1 & 0.2 & 3 & 0.7 & & 1 & 0.3 & 1 & 0.3 & 2 & 0.9 & & 4 & 0.4 \\
\hline \multirow[t]{2}{*}{ Hypoplasia } & Absent & 479 & 96.7 & 404 & 95.4 & 0.39 & 281 & 96.5 & 387 & 96.2 & 215 & 95.5 & 0.86 & 883 & 96.1 \\
\hline & Present & 16 & 3.3 & 19 & 4.6 & & 10 & 3.5 & 15 & 3.8 & 10 & 4.5 & & 35 & 3.9 \\
\hline \multirow[t]{2}{*}{ Hypomineralised Second molar } & Absent & 485 & 97.9 & 415 & 98.1 & 1.00 & 285 & 97.9 & 395 & 98.2 & 220 & 97.7 & 0.87 & 900 & 98.0 \\
\hline & Present & 10 & 2.1 & 8 & 1.9 & & 6 & 2.1 & 7 & 1.8 & 5 & 2.3 & & 18 & 2.0 \\
\hline \multirow[t]{2}{*}{ Fluorosis } & Absent & 491 & 99.2 & 421 & 99.5 & 0.69 & 288 & 98.9 & 400 & 99.5 & 224 & 99.5 & 0.68 & 912 & 99.3 \\
\hline & Present & 4 & 0.8 & 2 & 0.5 & & 3 & 1.1 & 2 & 0.5 & 1 & 0.5 & & 6 & 0.7 \\
\hline Amelogenesis imperfecta & Absent & 491 & 99.2 & 420 & 99.3 & 1.00 & 290 & 99.7 & 399 & 99.2 & 222 & 98.6 & 0.44 & 911 & 99.2 \\
\hline & Present & 4 & 0.8 & 3 & 0.7 & & 1 & 0.3 & 3 & 0.8 & 3 & 1.4 & & 7 & 0.8 \\
\hline
\end{tabular}

none have explored the association between ECC, fluorosis, and amelogenesis imperfecta.

One strength of this study is the method of data collection: the use of a household survey from enumeration sites marked for population surveys in Nigeria. This method increased the appropriate representation of the study population through the study-sampling approach, and our findings are more generalizable to 3-5-year old children in this region. In addition, the household survey is an appropriate recruitment strategy for reaching preschool-aged children who would not be recruited through school surveys.
The study showed that the prevalence of DDA in the primary dentition of preschoolers was lower than the 11.3 and $16.1 \%$ reported in children with mixed dentition in earlier studies, [19] but higher than the $2.2 \%$ reported in the permanent dentition of study participants in Nigeria [6]. The prevalence of DDA reported in this study is higher than 1.8 to $2.5 \%$ that was reported for preschool children in Brazil [21].

The prevalence of enamel hypoplasia in this population is lower than the $15.5 \%$ reported in preschool children in Brazil [22] and 7.6\% reported in 6-36-month old children in Tanzania [23]. Also, a study conducted on 
Table 2 Prevalence of clinically diagnosed developmental dental hard tissue anomalies by caries and oral hygiene status in preschool children in lle-lfe $(\mathrm{N}=918)$

\begin{tabular}{|c|c|c|c|c|c|c|c|c|c|c|c|c|c|c|c|}
\hline \multirow[t]{3}{*}{ Variables } & & \multicolumn{5}{|c|}{ Early childhood caries } & \multicolumn{7}{|c|}{ Oral hygiene status } & \multirow{2}{*}{\multicolumn{2}{|c|}{$\begin{array}{l}\text { TOTAL } \\
N=918\end{array}$}} \\
\hline & & \multicolumn{2}{|c|}{$\begin{array}{l}\text { Absent } \\
N=875\end{array}$} & \multicolumn{2}{|l|}{$\begin{array}{l}\text { Present } \\
n=43\end{array}$} & \multirow[t]{2}{*}{$\begin{array}{l}p- \\
\text { value }\end{array}$} & \multicolumn{2}{|c|}{ Good $n=613$} & \multicolumn{2}{|c|}{ Fair $n=267$} & \multicolumn{2}{|c|}{ Poor $n=38$} & \multirow[t]{2}{*}{$\begin{array}{l}p- \\
\text { value }\end{array}$} & & \\
\hline & & Number & $\%$ & Number & $\%$ & & Number & $\%$ & Number & $\%$ & Number & $\%$ & & Number & $\%$ \\
\hline \multirow[t]{2}{*}{ Supernumerary } & Absent & 871 & 99.5 & 43 & 100.0 & 1.00 & 610 & 99.5 & 267 & 100.0 & 37 & 97.4 & 0.10 & 897 & 99.6 \\
\hline & Present & 4 & 0.5 & 0 & 0.0 & & 3 & 0.5 & 0 & 0.0 & 1 & 2.6 & & 4 & 0.4 \\
\hline \multirow[t]{2}{*}{ Supplemental } & Absent & 869 & 99.3 & 43 & 100.0 & 1.00 & 609 & 99.3 & 266 & 99.6 & 37 & 97.4 & 0.28 & 896 & 99.3 \\
\hline & Present & 6 & 0.7 & 0 & 0.0 & & 4 & 0.7 & 1 & 0.4 & 1 & 2.6 & & 6 & 0.7 \\
\hline \multirow[t]{2}{*}{ Mesiodens } & Absent & 868 & 99.2 & 43 & 100.0 & 1.00 & 610 & 99.5 & 265 & 99.2 & 36 & 94.7 & 0.03 & 889 & 99.2 \\
\hline & Present & 7 & 0.8 & 0 & 0.0 & & 3 & 0.5 & 2 & 0.8 & 2 & 5.3 & & 7 & 0.8 \\
\hline \multirow[t]{2}{*}{ Hypodontia } & Absent & 867 & 99.1 & 43 & 100.0 & 1.00 & 608 & 99.2 & 267 & 100.0 & 35 & 92.1 & 0.03 & 896 & 99.1 \\
\hline & Present & 8 & 0.9 & 0 & 0.0 & & 5 & 0.8 & 0 & 0.0 & 3 & 7.9 & & 8 & 0.9 \\
\hline \multirow[t]{2}{*}{ Macrodontia } & Absent & 870 & 99.4 & 43 & 100.0 & 1.00 & 609 & 99.3 & 267 & 100.0 & 37 & 97.4 & 0.007 & 898 & 99.4 \\
\hline & Present & 5 & 0.6 & 0 & 0.0 & & 4 & 0.7 & 0 & 0.0 & 1 & 2.6 & & 5 & 0.6 \\
\hline \multirow[t]{2}{*}{ Microdontia } & Absent & 869 & 99.3 & 43 & 100.0 & 1.00 & 608 & 99.2 & 267 & 100.0 & 37 & 97.4 & 0.10 & 890 & 99.3 \\
\hline & Present & 6 & 0.7 & 0 & 0.0 & & 5 & 0.8 & 0 & 0.0 & 1 & 2.6 & & 6 & 0.7 \\
\hline \multirow[t]{2}{*}{ peg-shaped lateral } & Absent & 864 & 98.7 & 43 & 100.0 & 1.00 & 607 & 99.0 & 263 & 98.5 & 37 & 97.4 & 0.34 & 888 & 98.8 \\
\hline & Present & 11 & 1.3 & 0 & 0.0 & & 6 & 1.0 & 4 & 1.5 & 1 & 2.6 & & 11 & 1.2 \\
\hline \multirow[t]{2}{*}{ Dens evaginatus } & Absent & 871 & 99.5 & 43 & 100.0 & 1.00 & 610 & 99.5 & 267 & 100.0 & 37 & 97.4 & 0.10 & 898 & 99.6 \\
\hline & Present & 4 & 0.5 & 0 & 0.0 & & 3 & 0.5 & 0 & 0.0 & 1 & 2.6 & & 4 & 0.4 \\
\hline \multirow[t]{2}{*}{ Dens invaginatus } & Absent & 870 & 99.4 & 43 & 100.0 & 1.00 & 609 & 99.3 & 267 & 100.0 & 37 & 97.4 & 0.10 & 896 & 99.4 \\
\hline & Present & 5 & 0.6 & 0 & 0.0 & & 4 & 0.7 & 0 & 0.0 & 1 & 2.6 & & 5 & 0.6 \\
\hline \multirow[t]{2}{*}{ Talons cusp } & Absent & 869 & 99.3 & 43 & 100.0 & 1.00 & 608 & 99.2 & 267 & 100.0 & 37 & 97.4 & 0.10 & 893 & 99.3 \\
\hline & Present & 6 & 0.7 & 0 & 0.0 & & 5 & 0.8 & 0 & 0.0 & 1 & 2.6 & & 6 & 0.7 \\
\hline \multirow[t]{2}{*}{ Fusion/gemination } & Absent & 871 & 99.5 & 43 & 100.0 & 1.00 & 609 & 99.3 & 267 & 100.0 & 38 & 100.0 & 0.43 & 893 & 99.6 \\
\hline & Present & 4 & 0.5 & 0 & 0.0 & & 4 & 0.7 & 0 & 0.0 & 0 & 0.0 & & 4 & 0.4 \\
\hline \multirow[t]{2}{*}{ Hypoplasia } & Absent & 846 & 96.6 & 37 & 86.0 & $<$ & 585 & 95.3 & 262 & 98.1 & 36 & 94.7 & 0.10 & 865 & 96.1 \\
\hline & Present & 29 & 3.4 & 6 & 14.0 & 0.001 & 28 & 4.7 & 5 & 1.9 & 2 & 5.3 & & 35 & 3.9 \\
\hline \multirow{2}{*}{$\begin{array}{l}\text { Hypomineralised Second } \\
\text { molar }\end{array}$} & Absent & 860 & 98.2 & 40 & 93.0 & 0.05 & 599 & 97.7 & 264 & 98.9 & 37 & 97.4 & 0.37 & 879 & 98.0 \\
\hline & Present & 15 & 1.8 & 3 & 7.0 & & 14 & 2.3 & 3 & 1.1 & 1 & 2.6 & & 18 & 2.0 \\
\hline \multirow[t]{2}{*}{ Fluorosis } & Absent & 869 & 99.3 & 43 & 100.0 & 1.00 & 609 & 99.3 & 265 & 99.2 & 38 & 100.0 & 1.00 & 886 & 99.3 \\
\hline & Present & 6 & 0.7 & 0 & 0.0 & & 4 & 0.7 & 2 & 0.8 & 0 & 0.0 & & 6 & 0.7 \\
\hline Amelogenesis imperfecta & Absent & 868 & 99.2 & 43 & 100.0 & 1.00 & 607 & 99.0 & 267 & 100.0 & 37 & 97.4 & 0.10 & 886 & 99.2 \\
\hline & Present & 7 & 0.8 & 0 & 0.0 & & 6 & 1.0 & 0 & 0.0 & 1 & 2.6 & & 7 & 0.8 \\
\hline
\end{tabular}

the prevalence of enamel hypoplasia in 1- and 4-year-old children in Tanzania revealed that the prevalence of enamel hypoplasia ranged from 2.7 to $37.2 \%$, with prevalence higher in regions with lower fluoride content in drinking water [24]. Though the fluoride level of natural water in the study region (le-Ife) is $1.11-1.50 \mathrm{ppm}$ [25], like the fluoride level of the Dodoma region of Tanzania (1.5 ppm), the prevalence of enamel hypoplasia is less than that of the Dodoma region (5.7\%). The differences in the prevalence of enamel hypoplasia within and across countries may not be related to access to fluoride in drinking water, but this issue should be explored further.
We found no significant association between the presence of DDA and the prevalence of ECC and poor oral hygiene. However, we found that the proportion of children with ECC and poor oral hygiene who had a DDA was twice that of those who had no ECC and those who had good oral hygiene. The presence of a DDA increases the risk for plaque retention [6], which is a known risk factor for ECC in Nigeria [26]. A prior study had shown that DDA increased the risk for poor oral hygiene in the permanent dentition [6]. Although our study found no statistically significant association between DDA, ECC and oral hygiene status, the higher prevalence level of 
Table 3 Factors associated with presence of developmental dental tissue anomalies in the primary dentition (n-918)

\begin{tabular}{|c|c|c|c|c|c|c|}
\hline Variables & Prevalence Ratio & Standard Error & Z & $P$ value & \multicolumn{2}{|c|}{ [95\% Confidence Interval] } \\
\hline \multicolumn{7}{|l|}{ Sex } \\
\hline Male & 1.00 & - & - & - & - & - \\
\hline Female & 1.14 & 0.28 & 0.53 & 0.59 & 0.70 & 1.84 \\
\hline \multicolumn{7}{|c|}{ Socio-economic status } \\
\hline High & 1.00 & - & - & - & - & - \\
\hline Middle & 1.05 & 0.33 & 0.16 & 0.87 & 0.57 & 1.95 \\
\hline Low & 1.81 & 0.57 & 1.86 & 0.06 & 0.97 & 3.37 \\
\hline \multicolumn{7}{|c|}{ Oral hygiene status } \\
\hline Good & 1.00 & - & - & - & - & - \\
\hline Fair & 0.68 & 0.21 & -1.25 & 0.21 & 0.37 & 1.24 \\
\hline Poor & 2.03 & 0.84 & 1.72 & 0.09 & 0.91 & 4.56 \\
\hline \multicolumn{7}{|c|}{ Early childhood caries } \\
\hline Absent & 1.00 & - & - & - & - & - \\
\hline Present & 2.02 & 0.82 & 1.74 & 0.08 & 0.92 & 4.46 \\
\hline Constant & 0.06 & 0.02 & -10.35 & $<0.001$ & 0.03 & 0.10 \\
\hline
\end{tabular}

ECC and poor oral hygiene with a DDA may imply that children 3-5 years old with DDA should be treated as children with high risk for ECC and poor oral hygiene.

The study had a few limitations one of which is that this was a cross-sectional study, so no causal association between DDA, ECC and oral hygiene status can be inferred. The study was not representative of all preschool children in Nigeria; data were collected from only one of the 774 local government areas in the country. For the study population however, the finding from this study can be representative of the prevalence of DDA for the study population as the sample size was powered enough to address the study objective using a prevalence of $26.6 \%$ determined in a prior study conducted in the study population [5]. The prevalence of the DDA was however, an underestimation of the true prevalence of DDA in the study population as intra-bony lesions like supernumerary teeth, were not determined using radiographs. Despite these limitations, this study generated new and important information for the study population that can be useful for public health response.

\section{Conclusion}

We found ECC was associated with enamel hypoplasia and hypomineralized second primary molars. Also, the probability of a preschool child having ECC and having poor oral hygiene was increased in children with DDA though this finding did not reach statistical significance. In view of the known association between poor oral hygiene and ECC, screening for these DDA may be a strategic public health intervention to reduce the risk of children for ECC in the study population.

\section{Abbreviations}

Cl: Confidence Interval; DDA: Developmental Dental Anomalies; ECC: Early childhood caries; PR: Prevalence Ratio

\section{Acknowledgements}

We acknowledge and thank the study participants for the contributions they made to generating new knowledge.

\section{Authors' contributions}

The project was conceptualized by MOF. The project implementation was led by MOF and MOA. MOF wrote the first draft of the manuscript. MOA, MET, AA and TLF read and contributed to several versions of the manuscript. All authors read and approved the final manuscript.

\section{Funding}

No grant support for this study.

\section{Availability of data and materials}

Study-related data and materials and data collection tool are accessible on request from the lead author.

\section{Ethics approval and consent to participate}

Ethics approval for the study was obtained from the Health Research Ethics Committee of the Obafemi Awolowo University Teaching Hospitals' Complex in Ile-lfe (IRB/EC/0004553 and NHREC/27/02/2009a). Permission for conducting the study was also obtained from the Ife Central Local Government Area. Consent was obtained from mothers of children who participated in the study after they were duly informed about the objectives of the study, risks and benefits, voluntary nature of study participation, and freedom to withdraw from the study at any time. Written consent was obtained from all participants. No identifier was collected for each respondent. Study participants in each of the study communities were permitted to determine where the respondent should meet them.

Consent for publication

Not applicable.

\section{Competing interests}

MOF is a Sectional Editor and ME is an Associate Editor with the BMC Oral Health. 


\section{Author details}

${ }^{1}$ Obafemi Awolowo University, lle-lfe, Nigeria. ${ }^{2}$ Obafemi Awolowo University Teaching Hospitals' Complex, lle-lfe, Nigeria. ${ }^{3}$ Lagos State University, Lagos, Nigeria. ${ }^{4}$ Alexandria University, Alexandria, Egypt. ${ }^{5}$ San Diego State University, San Diego, CA, USA.

Received: 31 October 2019 Accepted: 15 December 2019

Published online: 31 December 2019

\section{References}

1. Seymen F, Folayan MO. Tooth eruption, tooth emergence and developmental dental anomalies. In: Folayan MO, editor. A compendium on oral health of children around the world: tooth eruption and developmental dental hard tissue anomalies, Cambridge Scholars, Lady Stephenson Library Newcastle upon Tyne NE6 2PA United Kingdom; 2019 p. 1-30.

2. Lukacs JR. Oral health in past populations: context, concepts and controversies. A companion to paleopathology. Chichester: Wiley-Blackwell; 2012. p. 553-81.

3. Sanusi SY, Temilola DO, Folayan MO. Where there is no data - thinking the future of tooth anatomy and tooth anomaly research. In: Folayan MO, editor. A compendium on oral health of children around the world: tooth eruption and developmental dental hard tissue anomalies, Cambridge Scholars, Lady Stephenson Library Newcastle upon Tyne NE6 2PA United Kingdom; 2019. p. 495-505.

4. Adeniji OO. Prevalence of dental anomalies in Nigerian school children. Niger Postgrad Med J. 1997;4:134-6

5. Temilola DO, Folayan MO, Fatusi O, et al. The prevalence, pattern and clinical presentation of developmental dental hard-tissue anomalies in children with primary and mix dentition from Ile-lfe, Nigeria. BMC Oral Health. 2014;14(1):125.

6. Folayan MO, Chukwumah NM, Popoola BO, et al. Developmental defects of the enamel and its impact on the oral health quality of life of children resident in Southwest Nigeria. BMC Oral Health. 2018;18(1):160.

7. Araoye MO. Research methodology with statistics for health and social sciences. Ilorin: Nathadex Publisher 2003;115(9):25-120.

8. Folayan MO, Kolawole KA, Oziegbe EO, et al. Prevalence, and early childhood caries risk indicators in preschool children in suburban Nigeria. BMC Oral Health. 2015:15(72):1-12.

9. UNESCO Report. Guide to the analysis and use of household survey and census education data. 2004. Available at http://www.uis.unesco.org/Library/ Documents/hhguide04-en.pdf. Assessed 17 July 2018.

10. Olusanya O, Okpere E, Ezimokhai M. The importance of social class in voluntary fertility control in a developing country. West Afr J Med. 1985;4(4): 205-12.

11. Folayan $\mathrm{M}$, Idehen $\mathrm{E}$, Ufomata $\mathrm{D}$. The effect of sociodemographic factors on dental anxiety in children seen in a suburban Nigerian hospital. Int J Paediatr Dent. 2003;13(1):20-6.

12. Greene JG, Vermillion JR. The simplified oral hygiene index. J Am Dent Assoc. 1964;68(1):7-13.

13. World Health Organisation (WHO). Oral health surveys: basic methods. 4th ed. Geneva: WHO; 1997.

14. Folayan MO, Alade MA. A compendium on oral health of children around the world: early childhood caries: Nova Science Publishers; 2017.

15. Weerheijm K. Duggal M, Mejare I, Papagiannoulis L, Koch G, Martens LC, et al. Paper presented at: judgement criteria for molar incisor hypomineralisation $(\mathrm{m} / \mathrm{H})$ in epidemiologic studies: a summary of the european meeting on $\mathrm{mlH}$ held in Athens, 2003.

16. Elfrink M, Schuller A, Weerheijm K, Veerkamp J. Hypomineralized second primary molars: prevalence data in Dutch 5-year-olds. Caries Res. 2008;42(4): 282-5.

17. Dean HT, Elvove E. Some epidemiological aspects of chronic endemic dental fluorosis. Am J Public Health Nations Health. 1936;26(6):567-75.

18. Seow WK. Clinical diagnosis and management strategies of amelogenesis imperfecta variants. Pediatr Dent. 1993;15(6):384-93.

19. Folayan MO, Oziegbe EO, Temilola DO, Orenuga OO. Nigeria. In: Folayan $\mathrm{MO}$, editor. A compendium on oral health of children around the world: tooth eruption and developmental dental hard tissue anomalies, Cambridge Scholars, Lady Stephenson Library Newcastle upon Tyne NE6 2PA United Kingdom; 2019. p. 286-309.
20. Oyedele T, Folayan M, Oziegbe E. Hypomineralised second primary molars: prevalence, pattern and associated co morbidities in 8-to 10-year-old children in lle-lfe, Nigeria. BMC Oral Health. 2016;16(1):65.

21. Bönecker M, Haddad AE, de Carvalho P, Arima LY, da Silva Oliveira EP. Brazil. In: Folayan MO, editor. A compendium on oral health of children around the world: tooth eruption and developmental dental hard tissue anomalies, Cambridge Scholars, Lady Stephenson Library Newcastle upon Tyne NE6 2PA United Kingdom; 2019. p. 62-82.

22. Ruschel HC, Vargas-Ferreira F, Tovo MF, Kramer PF, Feldens CA. Developmental defects of enamel in primary teeth: highly prevalent, unevenly distributed in the oral cavity and not associated with birth weight Eur Arch Paediatr Dent. 2019;20(3):241-8.

23. Masumo R, Bårdsen A, Åstrøm AN. Developmental defects of enamel in primary teeth and association with early life course events: a study of 6-36 month old children in Manyara, Tanzania. BMC Oral Health. 2013;13:21.

24. Matee MIN, Van't Hof MA, Maselle SY, Mikx FHM, van Palenstein Herlderman WH. Nursing caries, linear hypoplasia, and nursing and weaning habits in Tanzanian infants. Community Dent Oral Epidemiol. 1994;22:289-93.

25. Akpata ES, Danfillo IS, Otoh EC, Mafeni JO. Geographical mapping of fluoride levels in drinking water sources in Nigeria. Afr Health Sci. 2009;9(4): $227-33$.

26. Folayan MO, Kolawole KA, Oziegbe EO, Oyedele T, Oshomoji OV, Chukwumah NM, et al. Prevalence, and early childhood caries risk indicators in preschool children in suburban Nigeria. BMC Oral Health. 2015;15:72.

\section{Publisher's Note}

Springer Nature remains neutral with regard to jurisdictional claims in published maps and institutional affiliations.

Ready to submit your research? Choose BMC and benefit from:

- fast, convenient online submission

- thorough peer review by experienced researchers in your field

- rapid publication on acceptance

- support for research data, including large and complex data types

- gold Open Access which fosters wider collaboration and increased citations

- maximum visibility for your research: over $100 \mathrm{M}$ website views per year

At BMC, research is always in progress.

Learn more biomedcentral.com/submissions 